\title{
Chironomid Fauna in the Lower Reaches of the Nagara River, Japan
}

\author{
Koichiro KaWaI, Tetsuo Murakami, Shiro Kasuya \\ and Hiromichi IMABAYASHI
}

\begin{abstract}
The chironomid fauna of the lower reaches of the Nagara River was investigated on the basis of male adults emerging from bottom samples and those collected by light sampling. As a result, a total of 547 males representing 72 species were collected. For bottom samples, one occurrence peak was observed from May to June. The number of species increased remarkably with the distance from the rivermouth. For light samples, two peaks of species richness were observed, one in June and another from September to November. Larval distribution ranges differed considerably with species. Cryptochironomus albofasciatus was recorded from all the sites. Fourteen out of 18 major species were collected only at the upper reaches of more than $20 \mathrm{~km}$ from the rivermouth. This suggests the existence of a salinity barrier for freshwater species between $15 \mathrm{~km}$ and $20 \mathrm{~km}$. Clear differences in the seasonal occurrence of larvae were observed among species. For example, Polypedilum masudai and $P$. cultellatum occurred only from spring to summer and summer to autumn, respectively. Paratendipes albimanus was collected only by bottom sampling, suggesting the weak phototaxis of male adults of the species. In contrast, Smittia aterrima was collected only by light sampling, probably due to the terrestrial nature of the species.
\end{abstract}

Key words : chironomid fauna, eutrophication, lower reaches, seasonal occurrence

\section{INTRODUCTION}

The Nagara is a large-scale river discharging into Ise Bay and one of the Three Kiso Rivers, along with the Ibi and the Kiso Rivers. It originates from the Dainichigatake $(1709 \mathrm{~m})$ of the Ryohaku mountain chain and is $166 \mathrm{~km}$ in extended main flow length with $1985 \mathrm{~km}^{2}$ of catchment area. World-wide attention has recently been focused on this river due to the alleged necessity for dam construction at the rivermouth. Nevertheless, only fragmentary knowledge about the Nagara's chironomid fauna has been accumulated to date. SASA (1989a) investigated the chironomid fauna of the river's lower reaches only by collecting adult midges attracted to various light sources along the river in Gifu City, recording 28 species belonging to 17 genera. 
However, there seem to be no studies on the fauna by a more direct method, i.e., collection of bottom samples and identification of emerging adults. The present study was intended to clarify the whole chironomid fauna of the river's lower reaches by such a direct method before dam construction makes that impossible. The collecting of adults emerging from the bottom samples was supplemented by those attracted to lights.

\section{MATERIALS AND METHODS}

A total of six sampling sites were set at about $5 \mathrm{~km}$ intervals along the lower reaches of the Nagara from the rivermouth (Fig. 1).

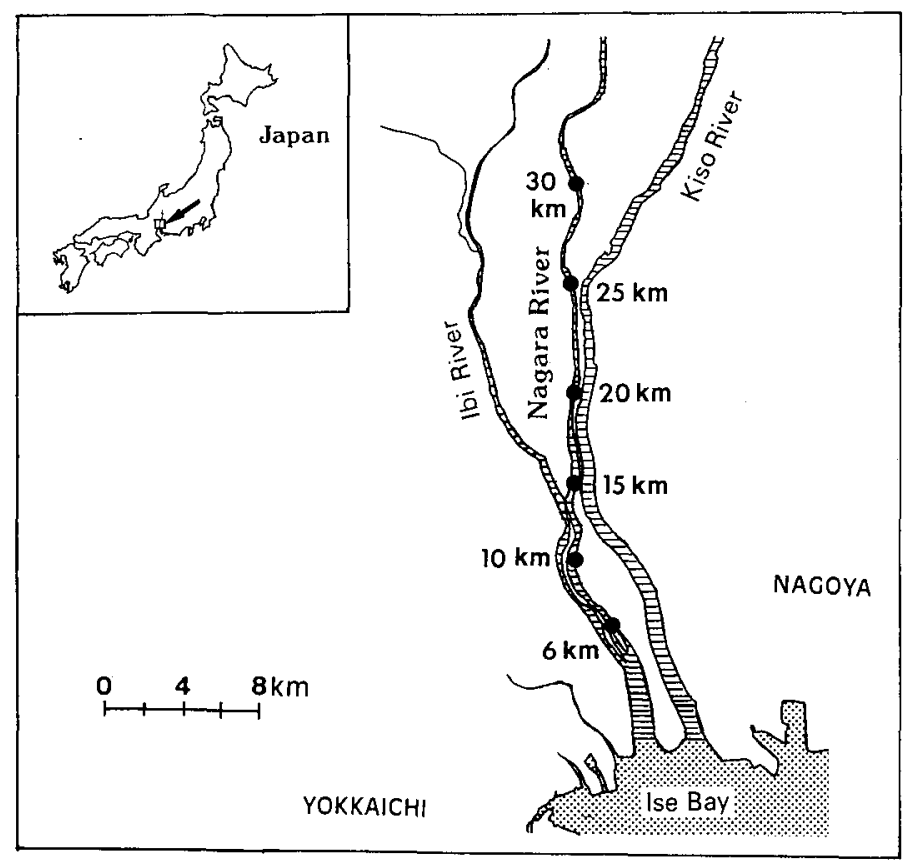

Fig. 1. Map of the lower reaches of the Nagara River, showing 6 sampling sites.

Bottom sampling was performed once a month from April 1993 through March 1994 at all the sites. Samples were collected using a $50 \times 50 \mathrm{~cm}$ quadrat. Sand or gravel in the quadrat were collected in plastic bags up to a depth of about $3 \mathrm{~cm}$, transported to the laboratory and put into containers $(\phi 30 \mathrm{~cm} \times \mathrm{H} 15 \mathrm{~cm})$. After pouring dechlorinated water to a $10 \mathrm{~cm}$ level and covering with a nylon net, the containers were incubated at room temperature for at least two months with vigorous aeration, and the emerging midges were collected daily. A total of 72 bottom samples were collected.

Light sampling was performed from July 1993 through June 1994 at the $15 \mathrm{~km}$ and $20 \mathrm{~km}$ sites, taking advantage of the light emitted by vending machines for drinks, etc., set on or near the riverbank. Adults attracted to one vending machine per site for 15 consecutive minutes $\quad(7: 00 \mathrm{pm}-12: 00$ 
pm) were collected for a total of 24 samples.

For species identification, only male adult specimens were mounted onto slides by the procedure described in SASA et al. (1980) and identified mainly using the keys provided by PINDER (1978), SASA (1989b) and WIEDERHOLM (1989). Species which could not be identified by any available key were given the scientific name of the nearest species, e.g., Polypedilum sp. nr. sagittiferum. In the absense of a closely related species, they were represented as, e.g., Dicrotendipes sp.

For an analysis of the physicochemical properties of the river water, surface samples were collected at each site simultaneously with the chironomid sampling. Chlorinity was measured by an electrolyte autoanalyzer (NOVA5 + 5, nova biomedical, MA, USA). COD and total-P were measured according to the methods of JIS-K0102.

\section{RESULTS}

Physicochemical properties of the water are listed in Table 1. Mean chlorinity was lower than $10 \mathrm{mEq} \mathrm{l^{-1 }}$ between the $30 \mathrm{~km}$ and $15 \mathrm{~km}$ sites. It began to drastically increase at $10 \mathrm{~km}$ and rose to about $90 \mathrm{mEq} \mathrm{l^{-1 }}$ at $6 \mathrm{~km}$. Mean COD value was above $4.0 \mathrm{mgO} \mathrm{l}^{-1}$ at $30 \mathrm{~km}$, but decreased remarkably at $25 \mathrm{~km}$, reaching its lowest at $15 \mathrm{~km}$. It began to rise again at $10 \mathrm{~km}$ and was above 5.0 at $6 \mathrm{~km}$. The mean values of total-P held steady between 6 $\mathrm{km}$ and $25 \mathrm{~km}$, but rose slightly at $30 \mathrm{~km}$.

Table 1. Water quality in relation to distance from the rivermouth. Mean $\pm S D$ of monthly data from May '93 to June '94 were represented.

\begin{tabular}{cccc}
\hline $\begin{array}{l}\text { Distance from } \\
\text { rivermouth }(\mathrm{km})\end{array}$ & $\mathrm{Cl}\left(\mathrm{mEq} \mathrm{l}^{-1}\right)$ & $\mathrm{COD}\left(\mathrm{mgO} \mathrm{l}^{-1}\right)$ & total-P $\left(\mathrm{mg} \mathrm{l}^{-1}\right)$ \\
\hline 6 & $89.9 \pm 59.5$ & $5.15 \pm 3.91$ & $0.077 \pm 0.041$ \\
10 & $29.2 \pm 25.0$ & $2.76 \pm 1.15$ & $0.080 \pm 0.031$ \\
15 & $9.0 \pm 2.1$ & $2.51 \pm 0.66$ & $0.076 \pm 0.025$ \\
20 & $8.3 \pm 1.6$ & $2.54 \pm 0.56$ & $0.070 \pm 0.013$ \\
25 & $8.4 \pm 1.5$ & $2.98 \pm 0.60$ & $0.080 \pm 0.025$ \\
30 & $8.7 \pm 1.5$ & $4.36 \pm 1.04$ & $0.109 \pm 0.028$ \\
\hline
\end{tabular}

Table 2. Number of species and males of the subfamilies or tribes, collected by two sampling methods.

\begin{tabular}{lccccccc}
\hline \multirow{2}{*}{$\begin{array}{l}\text { Subfamily } \\
\text { or tribe }\end{array}$} & \multicolumn{3}{c}{ No. of species } & & \multicolumn{3}{c}{ No. of males } \\
\cline { 2 - 4 } \cline { 7 - 8 } \cline { 6 - 8 } & Bottom & Light & Total & & Bottom & Light & Total \\
\hline Tanypodinae & 5 & 2 & 7 & & 11 & 2 & 13 \\
Diamesinae & 1 & 0 & 1 & & 1 & 0 & 1 \\
Orthocladiinae & 16 & 12 & 22 & & 48 & 44 & 92 \\
Chironominae & 33 & 28 & 42 & & 338 & 103 & 441 \\
(Chironomini) & $(24)$ & $(20)$ & $(31)$ & & $(239)$ & $(81)$ & $(320)$ \\
(Tanytarsini) & $(9)$ & $(8)$ & $(11)$ & $(99)$ & $(22)$ & $(121)$ \\
\hline Total & 55 & 42 & 72 & & 398 & 149 & 547 \\
\hline
\end{tabular}


Table 3. List of species recorded.

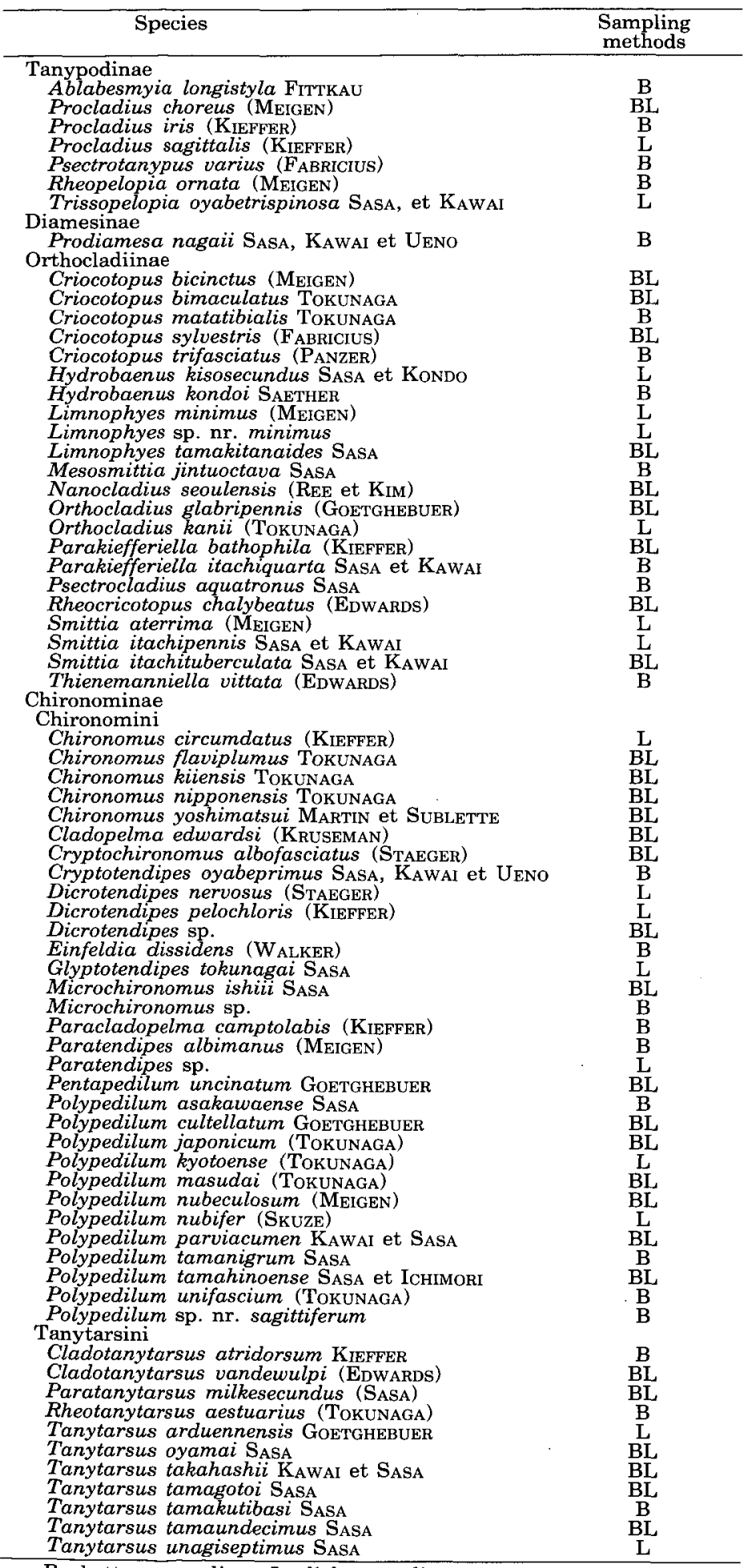

B : bottom sampling ; L : light sampling 
The Number of species and number of males collected by two sampling methods are listed in Table 2. A total of 547 males representing 72 species were collected. The subfamily Chironominae was predominant in both number of species and number of males. Within the subfamily, the tribe Chironomini greatly outnumbered the Tanytarsini in both species and males. More than 40 species were recorded both by bottom and light sampling. All the species collected are listed in Table 3. Limnophyes sp. nr. minimus, Dicrotendipes sp., Microchironomus sp., Paratendipes sp. and Polypedilum sp. nr. sagittiferum are possibly new species since they could not be identified by any available key. In this study, Ablabesmyia longistyla and Cladotanytarsus atridorsum were the first recorded from Japan. No less than 12 species belonging to a single genus Polypedilum were collected. Twenty-four and 17 species were collected only by bottom and light sampling, respectively, while 31 species were collected by both sampling methods.

The occurrence of each subfamily or tribe by month and site for bottom samples is shown in Fig. 2. A peak of larval occurrence was observed from May to June. Chironomini predominated in most seasons and at most sites both in numbers of species and males. Tanytarsini occurred from spring to early summer in rather large numbers. Total numbers of species and males generally increased with the distance from the rivermouth. Only Chironomini was recorded at the $6 \mathrm{~km}$ and $10 \mathrm{~km}$ sites. The numbers of species and males of the subfamily Orthocladiinae were greatest at $30 \mathrm{~km}$.

(A)

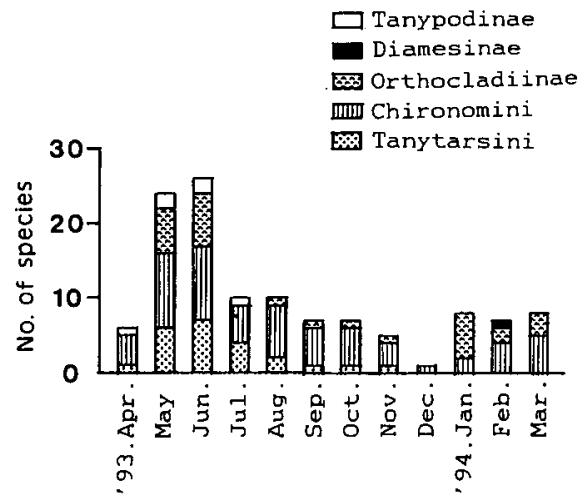

(B)
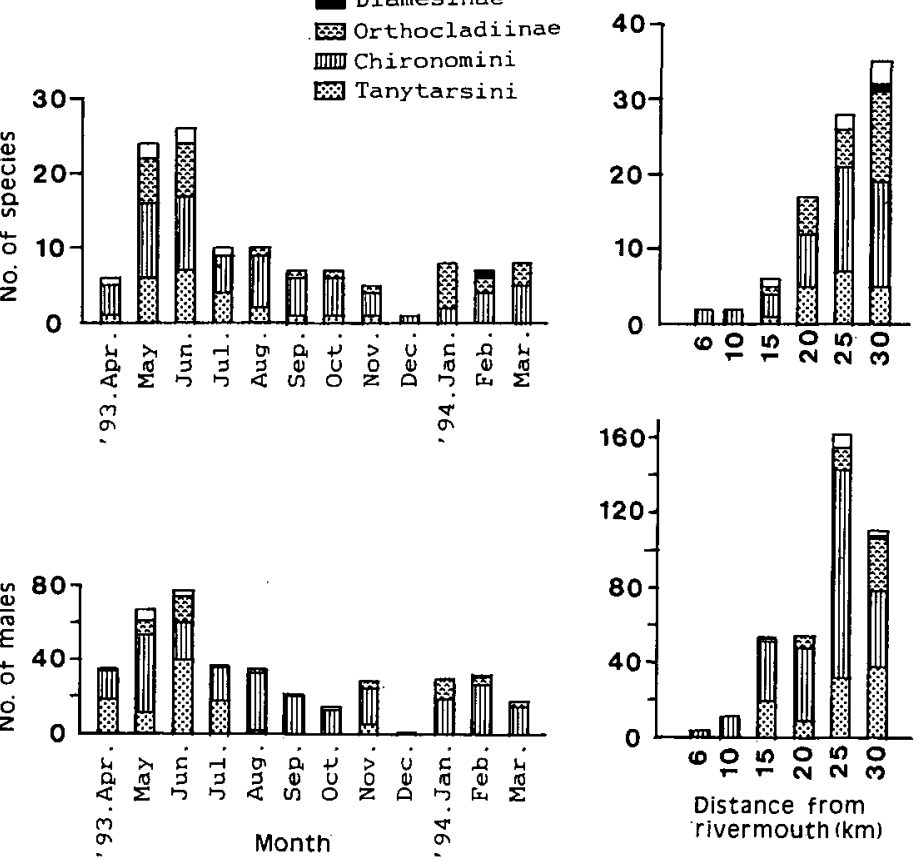

Fig. 2. Occurrence of each subfamily or tribe in bottom samples by month and site.

(A) Number of species; (B) Number of male individuals. 
The occurrence of each subfamily or tribe by month and site for light samples is shown in Fig. 3. Two distinct peaks of seasonal occurrence were observed, one from June to July, the other from September to November. Chironomini predominated from June to October, and Orthocladiinae from November to March in both numbers of species and males.

Far higher numbers of species and males were recorded at $15 \mathrm{~km}$ than at $20 \mathrm{~km}$. Chironomini predominated at $15 \mathrm{~km}$ while Chironomini and Orthocladiinae were co-dominant at $20 \mathrm{~km}$ in number of males.

(A)

(B)
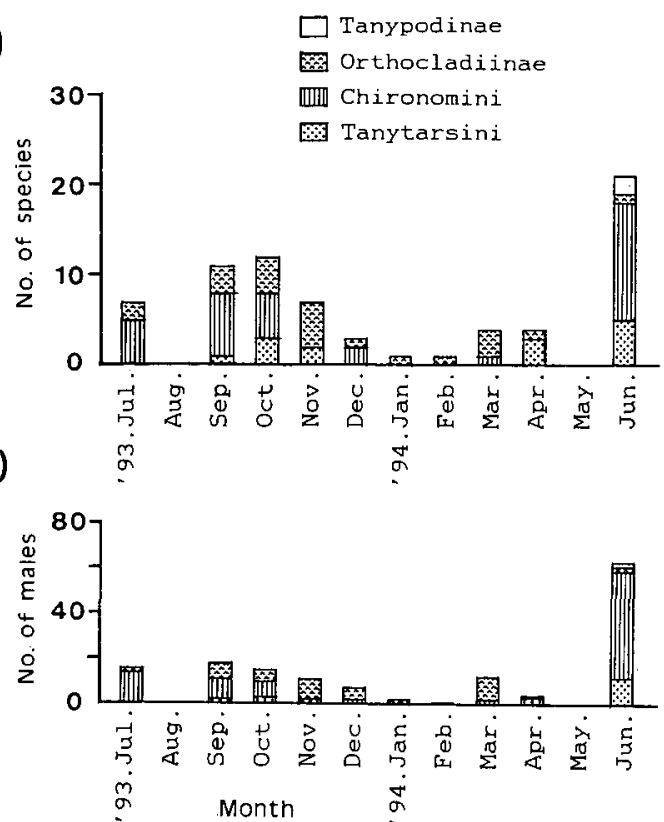
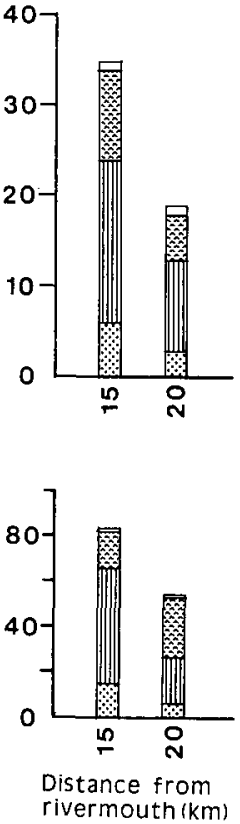

Fig. 3. Occurrence of each subfamily or tribe in bottom samples by month and site.

(A) Number of species; (B) Number of male individuals. .

Distribution ranges of the common species collected by bottom sampling are shown in Table 4. Cryptochironomus albofasciatus was distributed over all the sites. Cladopelma edwardsi was recorded at $10 \mathrm{~km}$ and $25 \mathrm{~km}$ sites. Polypedilum masudai and Dicrotendipes sp. were distributed between $15 \mathrm{~km}$ and $25 \mathrm{~km}$. The other species were recorded only at $\geqq 20 \mathrm{~km}$ upstream from the rivermouth. Parakiefferiella bathophila, Chironomus kiiensis and C. yoshimatsui were recorded only at $25 \mathrm{~km}$ and $30 \mathrm{~km}$.

The seasonal occurrence patterns of the common species collected by bottom sampling are shown in Table 5. Polypedilum masudai, Cricotopus bimaculatus and Cladotanytarsus vanderwulpi; Polypedilum cultellatum, Chironomus kiiensis and Polypedilum japonicum ; and Parakiefferiella bathophila occurred from spring to summer, summer to autumn and autumn to 
Table 4. Distribution ranges of species collected by bottom sampling. Number of samples containing each species are represented. Only the species which were collected at least in three samples are listed.

\begin{tabular}{|c|c|c|c|c|c|c|}
\hline \multirow[t]{2}{*}{ Species } & \multicolumn{6}{|c|}{$\mathrm{km}$ from rivermouth } \\
\hline & 6 & 10 & 15 & 20 & 25 & 30 \\
\hline Cryptochironomus albofasciatus & 1 & 6 & 4 & 5 & 9 & 4 \\
\hline Cladopelma edwardsi & & 1 & & & 2 & \\
\hline Polypedilum masudai & & & 1 & 1 & 1 & \\
\hline Dicrotendipes sp. & & & 3 & & 4 & \\
\hline Cladotanytarsus vanderwulpi & & & & 2 & 1 & 1 \\
\hline Tanytarsus tamaundecimus & & & & 3 & 2 & 2 \\
\hline Tanytarsus takahashii & & & & 2 & 2 & 1 \\
\hline Polypedilum cultellatum & & & & 2 & 1 & 2 \\
\hline Tanytarsus tamagotoi & & & & 1 & 1 & 1 \\
\hline Polypedilum japonicum & & & & 1 & 2 & 1 \\
\hline Cricotopus bimaculatus & & & & 1 & 1 & 2 \\
\hline Nanocladius seoulensis & & & & 1 & 2 & 3 \\
\hline Paratendipes albimanus & & & & 3 & & 1 \\
\hline Polypedilum tamahinoense & & & & 3 & & 1 \\
\hline Orthocladius glabripennis & & & & 1 & & 3 \\
\hline Parakiefferiella bathophila & & & & & 2 & 1 \\
\hline Chironomus kiiensis & & & & & 1 & 2 \\
\hline Chironomus yoshimatsui & & & & & 1 & 3 \\
\hline
\end{tabular}

Table 5. Seasonal occurrence of species collected by bottom sampling. Number of samples containing each species are represented. Only the species which were collected at least in three samples are listed.

\begin{tabular}{lcccc}
\hline \multicolumn{1}{c}{ Species } & \multicolumn{5}{c}{ Spring } & Summer & Autumn & Winter \\
& $3-5$ & $6-8$ & $9-11$ & $12-2$ \\
\hline Polypedilum masudai & 2 & 1 & & \\
Cricotopus bimaculatus & 2 & 2 & & \\
Cladotanytarsus vanderwulpi & 1 & 3 & & \\
Polypedilum cultellatum & & 4 & 1 & \\
Chironomus kiiensis & & 2 & 1 & \\
Polypedilum japonicum & & 2 & 2 & \\
Parakiefferiella bathophila & & & 2 & 1 \\
Dicrotendipes sp. & 3 & 2 & 2 & \\
Cladopelma edwardsi & 1 & 1 & 1 & \\
Tanytarsus tamagotoi & 1 & 1 & 1 & \\
Polypedilum tamahinoense & 1 & 1 & 2 & \\
Tanytarsus takahashii & 1 & 3 & 1 & \\
Tanytarsus tamaundecimus & 1 & 3 & 3 & \\
Nanocladius seoulensis & 3 & 2 & & 1 \\
Chironomus yoshimatsui & 2 & 1 & & 1 \\
Orthocladius glabripennis & 1 & & 1 & 2 \\
Paratendipes albimanus & & 2 & 1 & 1 \\
Cryptochironomus albofasciatus & 7 & 8 & 10 & 4 \\
\hline
\end{tabular}


winter, respectively. Dicrotendipes sp., Cladopelma edwardsi, Tanytarsus tamagotoi, etc.; Nanocladius seoulensis and Chironomus yoshimatsui; Orthocladius glabripennis; and Paratendipes albimanus occurred in all seasons except winter, autumn, summer and spring, respectively. Cryptochironomus albofasciatus occurred in all seasons.

The compositions of the major species are compared between two sampling methods at $15 \mathrm{~km}$ and $20 \mathrm{~km}$ (Table 6). Paratendipes albimanus and Polypedilum tamahinoense were collected at $20 \mathrm{~km}$ only by bottom sampling, while Smittia aterrima, Microchironomus ishiii, Limnophyes minimus, etc. were collected at both sites only by light sampling. Tanytarsus unagiseptimus was collected at $15 \mathrm{~km}$ only by light sampling. On the other hand, Cryptochironomus albofasciatus and Polypedilum masudai were collected at both sites using both sampling methods. Dicrotendipes sp. was collected at $15 \mathrm{~km}$ by both methods, but at $20 \mathrm{~km}$ only by light sampling. Polypedilum japonicum and Tanytarsus oyamai were collected at $20 \mathrm{~km}$ by both methods, but at $15 \mathrm{~km}$ only by light sampling. Tanytarsus tamagoto $i$ was collected at $20 \mathrm{~km}$ by both methods. Tanytarsus takahashii, T. tamaundecimus and Cladotanytarsus vanderwulpi were collected at $15 \mathrm{~km}$ by light sampling and at $20 \mathrm{~km}$ by bottom sampling.

Table 6. Comparison of collected species by two sampling methods at $15 \mathrm{~km}$ and $20 \mathrm{~km}$. Number of samples containing each species are represented. Only the species which were collected at least in three samples are listed.

\begin{tabular}{llllll}
\hline \multicolumn{1}{c}{ Species } & \multicolumn{2}{c}{$15 \mathrm{~km}$} & & \multicolumn{2}{c}{$20 \mathrm{~km}$} \\
\cline { 2 - 3 } \cline { 5 - 6 } & Bottom & Light & & Bottom & Light \\
\hline Paratendipes albimanus & & & 3 & \\
Polypedilum tamahinoense & & & 3 & \\
Cryptochironomus albofasciatus & 4 & 2 & & 5 & 1 \\
Polypedilum masudai & 1 & 3 & & 1 \\
Dicrotendipes sp. & 3 & 2 & & 1 \\
Polypedilum japonicum & & 1 & & 1 \\
Tanytarsus oyamai & & 1 & 1 & 1 \\
Tanytarsus tamagotoi & & & 1 & 2 \\
Tanytarsus takahashii & & 3 & 2 & \\
Tanytarsus tamaundecimus & & 1 & 3 & \\
Cladotanytarsus vanderwulpi & & 1 & & 2 & \\
Smittia aterrima & & 3 & & 6 \\
Microchironomus ishiii & & 3 & & 1 \\
Limnophyes minimus & & 2 & & 2 \\
Cricotopus sylvestris & & 2 & & 1 \\
Polypedilum kyotoense & & 2 & & 1 \\
Chironomus yoshimatsui & & 1 & & 2 \\
Tanytarsus unagiseptimus & & 3 & & \\
\hline
\end{tabular}




\section{DISCUSSION}

In this study, two different sampling methods, i.e., sampling of adults emerging from bottom samples and of adults attracted to lights, were used in view of clarifying the whole chironomid fauna of the lower Nagara River. As a result, no less than 72 species were recorded. Among them, 24 were collected only by bottom sampling and 17 species only by light sampling, although 31 species were collected by both methods (Table 3). Therefore, a combination of the two sampling methods is considered much more effective for an investigation of the entire fauna than a single method.

Forty-two species were recorded from a total of 24 samples collected by light sampling at 2 sampling sites, $15 \mathrm{~km}$ and $20 \mathrm{~km}$, from the mouth of the Nagara River in this study (Table 2). SASA (1989a) has also collected 28 species attracted to various light sources in only two hours within a distance of about only $1 \mathrm{~km}$ along the Nagara in Gifu City (about $50 \mathrm{~km}$ from the rivermouth). However, it remains unclear whether these results reflect the richness of chironomid fauna of the lower Nagara River until the results of seasonal investigations of chironomids by light sampling are compiled for some rivers similar in scale.

Cryptochironomus albofasciatus was collected at all sites and in all seasons from 32 samples (Tables 4-6). This species, therefore, may characterize the water environment of the lower reaches of the river. BECK (1977) reported that some Cryptochironomus species require mesotrophic to eutrophic waters and are saprophobic or facultative. On the other hand, Chironomus yoshimatsui, a predominant species in highly polluted rivers (SASA et al., 1980), was collected from only 7 samples in this study (Tables $4-6$ ). These results, coupled with the record of no less than 72 species, may suggest that the lower Nagara River has not yet become environmentally detrimental to chironomids, although it has already been considerably eutrophicated.

Among all the species collected in this study, only one, Cryptochironomus albofasciatus, seems to be highly resistant to salinity, judging from its occurrence at brackish sites (Tables 1 and 4). However, at least 20 brackish species of seven genera, e.g., Dicrotendipes inouei and Chironomus salinarius, have been recorded from Japan (SASA, 1989b), none of which were collected in this study. This seems to be partly because the substrate types of bottom samples were restricted to sand and gravels. Thus, various substrate samples containing a variety of species with different lifestyles must be collected for clarification of the whole chironomid fauna.

In this study, only two species, Cryptochironomus albofasciatus and Cladopelma edwardsi, were recorded $\leqq 10 \mathrm{~km}$ upstream from the rivermouth (Table 4). This may be due to considerably high salinity in this range (Table 1). However, the occurrence of 14 of 18 major species limited to $\geqq$ $20 \mathrm{~km}$ upstream from the rivermouth suggests the existence of a salinity barrier for freshwater species in the bottom substrates between 15 and 20 $\mathrm{km}$ although there must be a salinity barrier in the surface water between 10 and $15 \mathrm{~km}$. In this context, Polypedilum masudai and Dicrotendipes sp. 
are also considered to be resistent to salinity to some extent. Moreover, all of these 14 supposedly freshwater species were also observed at $30 \mathrm{~km}$ where the eutrophication level was a little higher than at 20 and $25 \mathrm{~km}$ (Table 1). This result suggests that such a difference in the eutrophication level does not affect the distribution of those chironomid species.

There were no remarkable differences in the total number of species or composition of subfamily or tribe between bottom samples and light samples at $20 \mathrm{~km}$, whereas about 6 times as many species were collected by light sampling as by bottom sampling at $15 \mathrm{~km}$ (Figs. 2, 3). One reason for these results may be that the composition of sediment sizes in bottom samples at $15 \mathrm{~km}$ was unsuitable for many species of chironomid larvae, judging from the fact that fine-sediment dwellers, such as genera Paratendipes (WIEDERHOLM, 1989) and probably Tanytarsus, were collected from bottom samples at $20 \mathrm{~km}$, but not from those at $15 \mathrm{~km}$ (Table 6). Another possible reason is that some species of adult males may have been attracted to lights from surrounding waters, such as agricultural canals and rice paddies at $15 \mathrm{~km}$.

Cladotanytarsus vanderwulpi occurred only from spring to summer in this study (Table 5). UENO et al. (1993) reported the emergence of this species in May and August in Lake Kasumigaura. Polypedilum masudai and $P$. japonicum occurred from spring to summer and from summer to autumn, respectively, in this study. These results were compatible with those in Lake Kojima (SugurI et al., 1989) and those in Tokushima City (KIKUCHI et al., 1985), respectively. On the other hand, Cladopelma edwardsi occurred from spring to autumn in this study, whereas it emerges only in summer in North America (BECK, 1977). This discrepancy may be attributable to the geographical difference, i.e., disparities in average annual temperature, between these studies.

Paratendipes albimanus and Polypedilum tamahinoense were collected only by bottom sampling while Smittia aterrima, Microchironomus ishiii, Limnophyes minimus, etc. were collected only by light sampling (Table 6) . The male adults of the former group may have no or weak phototaxis, while the latter group may comprise terrestrial species which dwell in substrates other than sand and gravels, emerge from waters relevant to the Nagara River, or do live in sand but at a low density. Among the latter, Smittia aterrima is considered to be a terrestrial species or species whose larvae live in the soil of riverbanks or agricultural fields (WIEDERHOLM, 1989). Limnophyes minimus may also be a semiterrestrial or terrestrial species (WIEDER HOLM, 1989). Polypedilum kyotoense may have been attracted to lights from rice paddies near the river because this species is known to emerge from such paddies in large numbers (KIKUCHI et al., 1985 ; MATSUNO et al., 1991). Cricotopus sylvestris may have emerged from waterplants in the river since it much prefers waterplants to sediments as habitats (UENo et al., 1993).

In this study, sampling of male adults was performed under the illumination from vending machines usually equipped with white lamps. However, a light of about $350 \mathrm{~nm}$ in wavelength was reported to be most effective in collecting adults of Chironomus plumosus and Tokunagayusurika akamusi 
(Hirabayashi et al., 1993). In addition, a male adult of Chironomus yoshimatsui was shown to respond to sounds in a frequency range of 180-390 $\mathrm{H}_{z}$ (OGAWA and SATO, 1993). Therefore, such traps as are equipped with near ultraviolet lights and sounds of low to middle frequencies need to be introduced as standard sampling devices for more efficient adult male collection.

\section{REFFERENCES}

BECK, M. W. (1977) : Environmental requirements and pollution tolerance of common freshwater Chironomidae, $261 \mathrm{pp}$., Environmental Monitoring and Support Laboratory, U.S. Environmental Protection Agency, Cincinnati.

Hirabayashi, K., R. Nakazato, A. Ohara and T. Okino (1993) : A study on phototaxis for adult Chironomidae (Diptera) by artificial light in Lake Suwa. Jpn. J. Sanit. Zool., $44: 33-39$.

Kikuchi, M., T. Kikuchi, S. Okubo and M. SaSa (1985) : Observation on the seasonal prevalence of chironomid midges and mosquitoes by light traps set in a rice paddy area in Tokushima. Jpn. J. Sanit. Zool., 36: 333-342.

Matsuno, M., G. Murakami, Y. Adachi, Y. Adachi, M. Kayahara, T. OKada, R. ARakaWa, K. KaWAi and T. Igarashi (1991): Immunochemical quantification of the airborne chironomid allergens. Jpn. J. Allergol., $40: 51$ -59 (in Jàpanese).

OGaWA, K. and H. SATO (1993) : Relationship between male acoustic response and female wingbeat frequency in a chironomid midge, Chironomus yoshimatsui (Diptera : Chironomidae). Jpn. J. Sanit. Zool., 44 : 355-360.

Pinder, L. C. V. (1978) : A key to adult males of British chironomidae. Freshwat. Biol. Asoc. Sc. Publ. No. 37, $169 \mathrm{pp}+189$ figs.

SASA, M. (1989a) : Chironomid midges of some rivers in western Japan. Part 4. Chironomid species collected from Nagara River, Gifu. In Some characteristics of nature conservation within the chief rivers in Toyama Prefecture (The upper reach of Shou River). Res. Rep. Toyama Pref. Environ. Pollut. Res. Cent., [1989] : 65-69.

SASA, M. (1989b) : Chironomidae of Japan : Checklist of species recorded, key to males and taxonomic notes. Res. Rep. Natl. Inst. Environ. Stud., 125: 1-177.

Sasa, M., M. Yasuno, M. Ito and T. KikUchi (1980) : Studies on chironomid midges of the Tama River. Part.1. The distribution of chironomid species in a tributary in relation to the degree of pollution with sewage water. Res. Rep. Natl. Inst. Environ. Stud., 13:1-8.

Suguri, S., M. Harada, M. Sasa, A. Ishin, K. Itano and H. Matsuoka (1989) : A year-round survey of chironomid midges by light trap collections at Lake Kojima in Okayama Prefecture. Jpn. J. Sanit. Zool., 40:33-39.

Ueno, R., T. Iwakuma and S. Nohara (1993) : Chironomid fauna in the emergent plant zone of Lake Kasumigaura, Japan. Jpn. J. Limnol., 54 : 293-303.

WIEDERHolm, T. Ed. (1989) : Chironomidae of the Holarctic region. Keys and diagnoses. Part 3-Adult males. Ent. Scand. Suppl. 34 : 1-532.

Koichiro KAWAI : Laboratory of Ecology, Faculty of Applied Biological Science, Hiroshima University, 1-4-4, Kagamiyama, Higashi-hiroshima 739 （河合幸 
一郎：干 739 東広島市鏡山 1-4-4, 広島大学生物生産学部動物生態学研究 窒)

Shiro KASUYA : Department of Parasitology, Faculty of Medicine, Gifu University, 40, Tsukasa-cho, Gifu, 500 （粕谷志郎：干 500 岐阜市司町 40, 岐阜大学医学 部寄生虫学教室)

Tetsuo MURAKAMI : Environmental Pollution Research Institute of Nagoya City, 1 -13, Chudo-cho, Minami-ku, Nagoya 457 (村上哲生：干 475 名古屋市南区 忠道町 1-13, 名古屋市公害研究所)

Hiromichi IMABAYASHI : Laboratory of Ecology, Faculty of Applied Biological Science, Hiroshima University, 1-4-4, Kagamiyama, Higashi-hiroshima 739 (今林博道：干 739 東広島市鏡山 1-4-4, 広島大学生物生産学部動物生態学 研究室）

(Received : 4 July 1996 ; Accepted : 14 January 1997)

\section{長良川下流のユスリカ相}

河合幸一郎・粕谷志郎・村上哲生・今林博道

\section{摘要}

底質から羽化する雄成虫及び灯火に集まる雄成虫を採集して同定する力法により，長良 川下流域のユスリカ相を調べた。その結果, 計 72 種 547 個体の雄成虫が得られた。底質羽 化法の場合, 5 月から 6 月にかけて明らかな出現ピークが見られた。また, 河口から遠い定 点ほど多くの種が記録された。灯火サンプルの場合，6月と 9-11月の 2 回の出現ピーク が見られた。幼虫の分布する範囲は種間で明らかに異なっていた。すなわち，Cryptochironomus albofasciatus は全ての定点で採集された。底質採集の主要 18 種のうち 14 種は河 口から $20 \mathrm{~km}$ 以上上流の定点からのみ採集され，河床環境においては $15-20 \mathrm{~km}$ の間に 淡水種にとっての塩分バリアーが存在することが示唆された。また，幼虫の季節的な出現 についても種間で明らかな違いがみられた。例えば, Polypedilum masudai とP. cultellatumは，それぞれ春から夏と夏から秋のみ出現した。また，Paratendipes albimanus は 底質採集によってのみ，Smittia aterrima は灯火採集によってのみ記録され，これは，前者 の雄成出の走光性が弱いこと及び後者が陸生種であることに起因すると考えられた。 